\title{
Thermal chemical vapor deposition of epitaxial rhombohedral boron nitride from trimethylboron and ammonia
}

Laurent Souqui, Henrik Pedersen and Hans Högberg

The self-archived postprint version of this journal article is available at Linköping University Institutional Repository (DiVA):

http:// urn.kb.se/ resolve?urn=urn:nbn:se:liu:diva- 155543

N.B.: When citing this work, cite the original publication.

Souqui, L., Pedersen, H., Högberg, H., (2019), Thermal chemical vapor deposition of epitaxial rhombohedral boron nitride from trimethylboron and ammonia, J ournal of Vacuum Science \& Technology. A. Vacuum, Surfaces, and Films, 37(2), 020603. https:// doi.org/ 10.1116/1.5085192

Original publication available at:

https:/ / doi.org/ 10.1116/ 1.5085192

Copyright: AIP Publishing

http:// www.aip.org/ 


\section{Thermal chemical vapor deposition of epitaxial rhombohedral boron nitride from trimethylboron and ammonia}

Running title: CVD of epitaxial r-BN from $\mathrm{B}\left(\mathrm{CH}_{3}\right)_{3}$ and $\mathrm{NH}_{3}$

Running Authors: Souqui et al.

Laurent Souquia), Henrik Pedersen, Hans Högberg

Department of Physics, Chemistry and Biology (IFM), Linköping University, SE-581 83, Linköping, Sweden.

a) Electronic mail: laurent.souqui@liu.se

Epitaxial rhombohedral boron nitride films were deposited on $\alpha-\mathrm{Al}_{2} \mathrm{O}_{3}(001)$ substrates by chemical vapor deposition, using trimethylboron, ammonia, and with a low concentration of silane in the growth flux. The depositions were performed at temperatures from 1200 to $1485^{\circ} \mathrm{C}$, pressures from 30 to 90 mbar and N/B ratios from 321 to 1286 . The most favorable conditions for epitaxy were: a temperature of 1400 ${ }^{\circ} \mathrm{C}, \mathrm{N} / \mathrm{B}$ around 964, and pressures below 40 mbar. Analysis by thin film X-ray diffraction showed that most deposited films were polytype-pure epitaxial r-BN with an out-of-plane epitaxial relationship of r-BN[001] \| w-AlN[001] ॥ $\alpha-\mathrm{Al}_{2} \mathrm{O}_{3}[001]$ and with two in-plane relationships of $\mathrm{r}-\mathrm{BN}[110]\|\mathrm{w}-\mathrm{AlN}[110]\| \quad \alpha-\mathrm{Al}_{2} \mathrm{O}_{3}[100]$ and $\mathrm{r}-$ $\mathrm{BN}[110]\|\mathrm{w}-\mathrm{AlN}[110]\| \alpha-\mathrm{Al}_{2} \mathrm{O}_{3}[\overline{100}]$ due to twinning. 


\section{INTRODUCTION}

The trialkylboron triethylboron (TEB, $\left.\mathrm{B}\left(\mathrm{C}_{2} \mathrm{H}_{5}\right)_{3}\right)$ is commonly used as boron precursor in chemical vapor deposition (CVD) of boron-based thin films as it is less corrosive than the halides $\mathrm{BF}_{3}$ and $\mathrm{BCl}_{3}$, and less poisonous than diborane $\left(\mathrm{B}_{2} \mathrm{H}_{6}\right)$. In a seminal study, Lewis et al. ${ }^{1}$ compared the trialylborons TEB, trimethylboron (TMB, $\left.\mathrm{B}\left(\mathrm{CH}_{3}\right)_{3}\right)$ and tributylboron (TBB, $\left.\mathrm{B}\left(\mathrm{C}_{4} \mathrm{H}_{9}\right)_{3}\right)$ and suggested that TEB was the most suitable for depositing boron carbon films, judged mainly by the high $\mathrm{B} / \mathrm{C}$ ratio obtained. A recent study on the thermal gas phase chemistry of TEB in CVD² confirmed that the molecule is an efficient boron source at temperatures below 1000 ${ }^{\circ} \mathrm{C}$. TEB has been employed for CVD of boron carbides ${ }^{2,3}$, phosphides and arsenides ${ }^{4}$ and, of particular interest for this study, boron nitrides. ${ }^{5-13}$ TEB decomposes primarily by $\beta$-hydride elimination, offering a low-temperature synthesis route for boron-rich films ${ }^{1,2}$. On the contrary, a drawback is that the ethyl ligands are suggested to form $\mathrm{C}_{2} \mathrm{H}_{4}$ upon $\beta$-hydride elimination ${ }^{2}$, which will be reactive as CVD precursors at the high temperatures needed for the growth of boron nitride (around $1500{ }^{\circ} \mathrm{C}$ ) 5 ,9 and can therefore lead to carbon impurities in the BN films. From this perspective, TMB with only three carbon per boron is seemingly a promising alternative to TEB. In addition, TMB was recently shown to be an efficient boron precursor for high temperature deposition and suggested to form less reactive $\mathrm{CH}_{4}$ in an $\alpha$-elimination decomposition. ${ }^{14}$ However, fundamental studies on CVD of boron-based compounds using TMB are scarce. Manasevit et al. successfully deposited boron monophosphide and boron subarsenide from $\mathrm{TMB}^{4}$. For boron-nitride-based neutron detectors, Maity et al. deposited films from ${ }^{10} \mathrm{~B}$-enriched TMB and ammonia in a nitrogen ambient, ${ }^{15}$ 
but did not report on any characteristics of the process. Here, we present a fundamental CVD study for deposition of epitaxial rhombohedral boron nitride (r$\mathrm{BN}$ ) using TMB and ammonia in hydrogen ambient at temperatures ranging from 1200-1485 ${ }^{\circ} \mathrm{C}$, pressures from 30 to 90 mbar, N/B ratios ranging from 321 and 1286. We have added minute amounts of silane, as discussed in our previous study, a small partial pressure of silicon during CVD of $\mathrm{sp}^{2}$-BN from TEB was shown to improve the crystalline quality. ${ }^{16}$

\section{EXPERIMENTAL DETAILS}

BN films were deposited on $\alpha-\mathrm{Al}_{2} \mathrm{O}_{3}(001)$ for $120 \mathrm{~min}$ at temperatures of $1200,1300,1400$, and $1485{ }^{\circ} \mathrm{C}$ in a hot-wall CVD reactor kept at a base pressure below $10^{-7}$ mbar. The substrates were cut in $10 \times 10 \mathrm{~mm}^{2}$ pieces and were cleaned according to the following procedure: $3 \mathrm{~min}$ in an ultrasonic bath in acetone at $80{ }^{\circ} \mathrm{C}$, 3 min in an ultrasonic bath in ethanol at $80^{\circ} \mathrm{C}$, followed by standard clean 1 (SC1, $\mathrm{NH}_{3}: \mathrm{H}_{2} \mathrm{O}_{2}: \mathrm{H}_{2} \mathrm{O}$ with relative concentrations $1: 1: 26$ at $\left.80{ }^{\circ} \mathrm{C}\right)^{16}$ and standard clean 2 (SC2, $\mathrm{HCl}: \mathrm{H}_{2} \mathrm{O}_{2}: \mathrm{H}_{2} \mathrm{O}$ with relative concentrations $1: 1: 22$ at $80{ }^{\circ} \mathrm{C}$ ) ${ }^{17}$. The substrates were placed in the center of a tantalum-carbide-coated elliptical susceptor. Prior to $\mathrm{BN}$ deposition, the $\alpha-\mathrm{Al}_{2} \mathrm{O}_{3}$ substrates were heated to $1100{ }^{\circ} \mathrm{C}$ during $5 \mathrm{~min}$ in palladium membrane purified hydrogen gas $\left(\mathrm{H}_{2}\right)$, after which ammonia $\left(\mathrm{NH}_{3}, 99.999\right.$ $\%$, further purified with respect to water by a getter filter) was introduced and the temperature ramped up to the selected growth temperature for 10 min to form an insitu aluminum nitride buffer layer as previously reported in ${ }^{8,9,12} . \mathrm{H}_{2}$ was used as carrier gas for the boron precursor TMB (99.99 \% purity, Voltaix/Air Liquide Advance Materials, FL) as well as the nitrogen source $\mathrm{NH}_{3}$. TMB was flowed in a separate quartz liner to avoid the formation of the $\mathrm{H}_{3} \mathrm{~N}: \mathrm{B}\left(\mathrm{CH}_{3}\right)_{3}$ adduct $^{18}$. The N/B 
ratio was varied between 321 and 1286. From previous works ${ }^{16}$, silane $\left(\mathrm{SiH}_{4}, 99.999\right.$ \% purity, $2000 \mathrm{ppm}$ diluted in $99.9996 \% \mathrm{H}_{2}$ ) was inserted 2 min prior to growth. The process pressure was in the range of 30 to 90 mbar and regulated by a throttle valve. The growth temperature was monitored by a pyrometer (Heitronics KT81R, calibrated by silicon melting).

The deposited films were characterized by thin film X-ray scattering, electron microscopy and ion beam analysis. All diffractograms and reflectograms were PANalytical X'Pert PRO, using a Bragg-Brentano HD mirror with $1 / 2^{\circ}$ divergence and anti-scatter slits as primary optics and an X'Celerator detector with a $0.5 \mathrm{~mm}$ anti-scatter slit, 0.04 rad Soller slits and nickel $\mathrm{K} \beta$ filter as secondary optics. In plane measurements, as azimuthal scans ( $\varphi$-scans) and Glancing-Incidence Diffraction (GID) were acquired with a Phillips X'Pert MPD, using cross-slits $\left(2 \times 2 \mathrm{~mm}^{2}\right)$ with nickel $\mathrm{K} \beta$ filter as primary optics and a proportional detector (PW1711/96) equipped with a parallel plate collimator. The thickness of the film was estimated from scanning electron microscopy (SEM) using an accelerating voltage of $5 \mathrm{kV}$ and an inlens secondary electron detector. The analysis of the composition was performed by time-of-flight energy elastic recoil detection analysis (ToF-E ERDA). The measurements were carried out with a $36 \mathrm{MeV}^{127}$ iodine ion beam. The incident angle of primary ions and exit angle of recoils were both $67.5^{\circ}$ to the sample surface normal giving a recoil angle of $45^{\circ}$. The measured ToF-E ERDA spectra were converted into relative atomic concentration profiles using the Potku code ${ }^{19}$.

\section{RESULTS AND DISCUSSION}

\section{A. Structural characterization of the BN films}




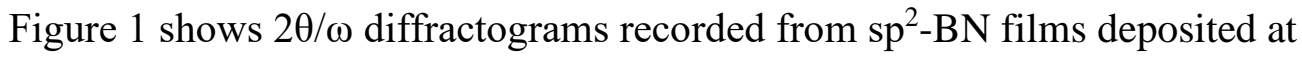
$1200,1300,1400$, and $1485^{\circ} \mathrm{C}$. At $1400{ }^{\circ} \mathrm{C}$ there are clear peaks positioned at $26.5^{\circ}$ and $54.5^{\circ}$ originated from the diffraction of $\mathrm{sp}^{2}-\mathrm{BN}(00 \ell)$ and the second order diffraction $(00 \underline{2 \ell})$, suggesting highly-oriented pyrolytic $\mathrm{BN}^{20}$ or textured h- $\mathrm{BN}^{21}$ or r$\mathrm{BN}^{22}$ on the nitridated $\alpha-\mathrm{Al}_{2} \mathrm{O}_{3}(001)$. We note that the growth temperature of $1400{ }^{\circ} \mathrm{C}$ is $100{ }^{\circ} \mathrm{C}$ lower than the temperature previously reported for TEB at similar growth conditions ${ }^{9}$. Increasing temperature to $1485^{\circ} \mathrm{C}$ or decreasing it to $1300{ }^{\circ} \mathrm{C}$, decreases the intensity of the $00 \ell$ peak and the second order diffraction peaks are no longer visible. At $1200{ }^{\circ} \mathrm{C}$, no diffraction peak is visible. As for deposition with $\mathrm{TEB}^{9}$, the deposition of high-quality $\mathrm{sp}^{2}$-BN films seems to be constrained to a narrow temperature window, albeit at $100{ }^{\circ} \mathrm{C}$ lower temperature. In addition, to the highintensity 006 peak from the sapphire substrate in all investigated films, the 002 diffraction peak of w-AlN was detected from $1200{ }^{\circ} \mathrm{C}$ and with 100 and 110 peaks visible for growth at $1485^{\circ} \mathrm{C}$. SEM measurements of cross sections showed that the average film thickness increased from $896 \pm 87 \mathrm{~nm}$ at $1200{ }^{\circ} \mathrm{C}$ to $1308 \pm 194 \mathrm{~nm}$ at $1485{ }^{\circ} \mathrm{C}$, corresponding to an average growth rate from $7.5 \pm 0.7 \mathrm{~nm} / \mathrm{min}$ to $10.9 \pm$ $1.6 \mathrm{~nm} / \mathrm{min}$. This is nearly three times faster than the growth rate of around 3.7 $\mathrm{nm} / \mathrm{min}$ obtained with the same concentration of TEB at $1500^{\circ} \mathrm{C}$. The films also presented a high roughness as $\mathrm{in}^{23}$. 


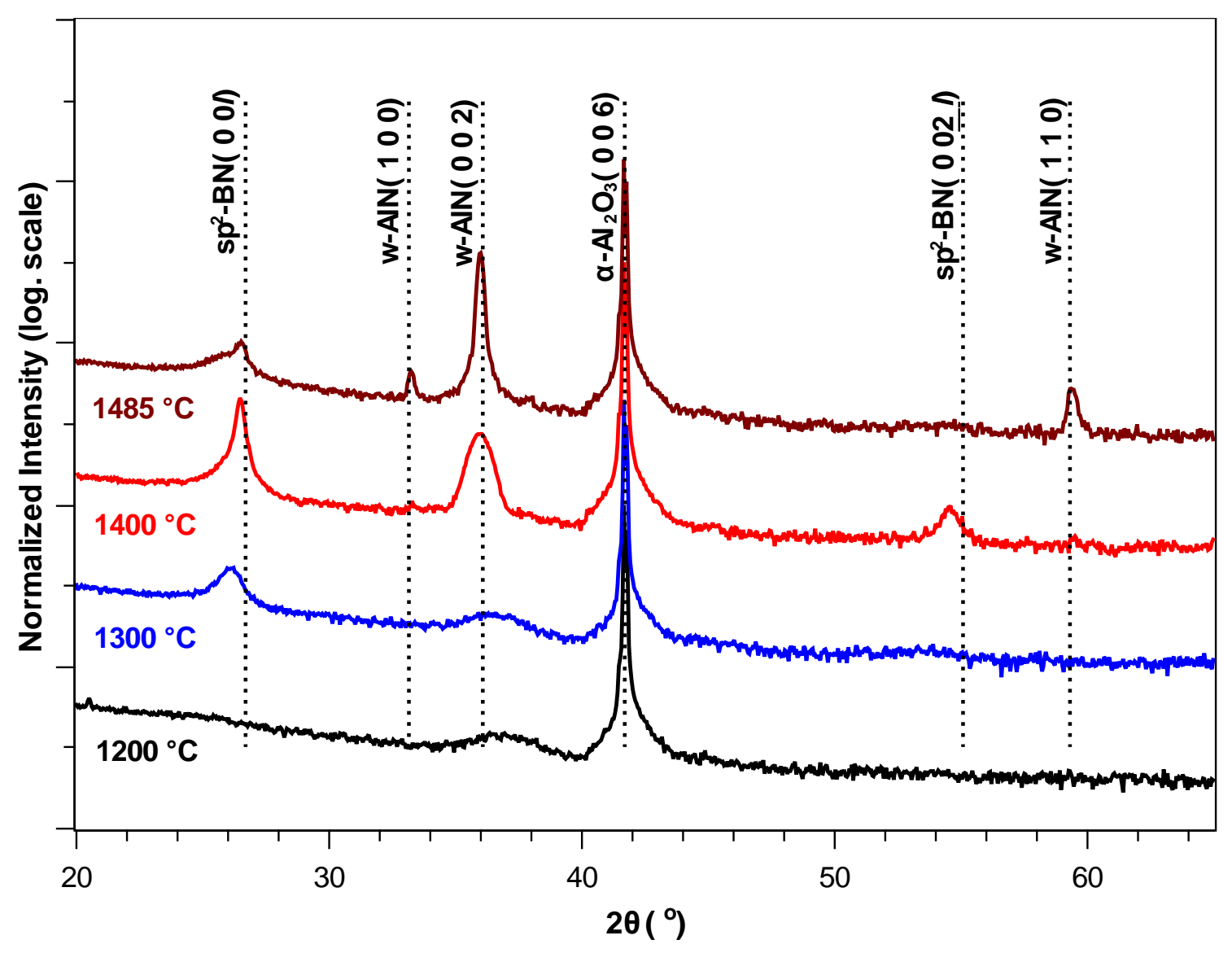

Using a combination of glancing incidence diffraction (GID) and $\varphi$-scans, we concluded that the films deposited on $\mathrm{AlN} / \alpha-\mathrm{Al}_{2} \mathrm{O}_{3}(001)$ were epitaxial already at $1300{ }^{\circ} \mathrm{C}$. The films deposited $1400{ }^{\circ} \mathrm{C}$ were most cases polytype-pure rhombohedral BN. The epitaxial relationships were $\mathrm{sp}^{2}-\mathrm{BN}[001]\|\mathrm{w}-\mathrm{AlN}[001]\| \alpha-\mathrm{Al}_{2} \mathrm{O}_{3}[001]$ (Figure 1) out-plane and, $\mathrm{sp}^{2}-\mathrm{BN}[110]\|\mathrm{w}-\mathrm{AlN}[110]\| \alpha-\mathrm{Al}_{2} \mathrm{O}_{3}[100]$ in-plane as shown by the GID diffractogram in Figure 2.(a). 
(a)

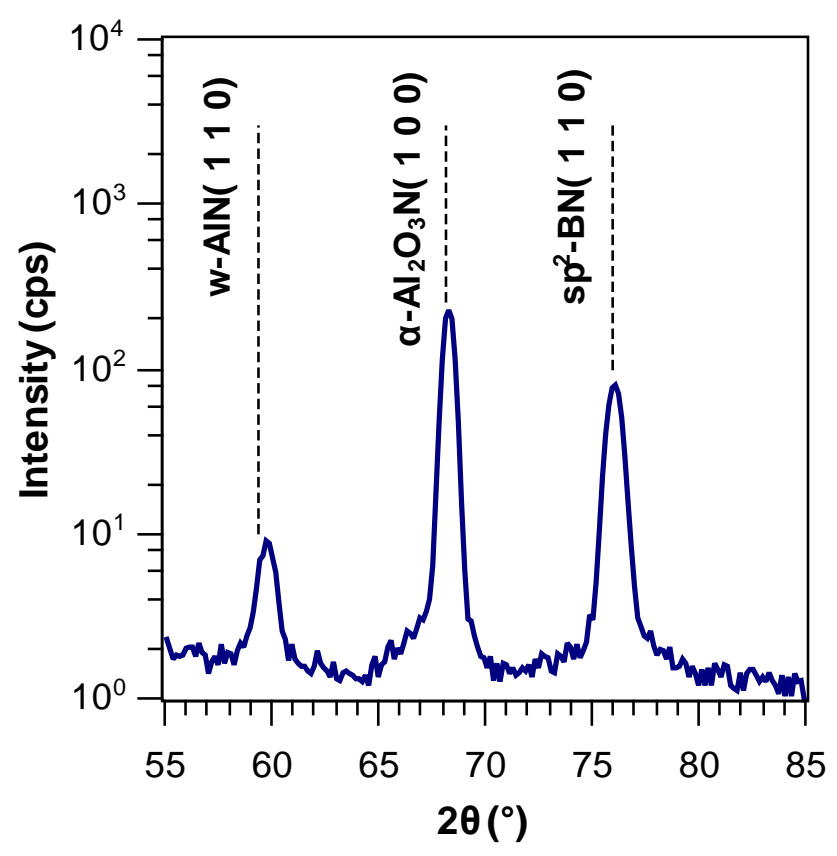

(b)

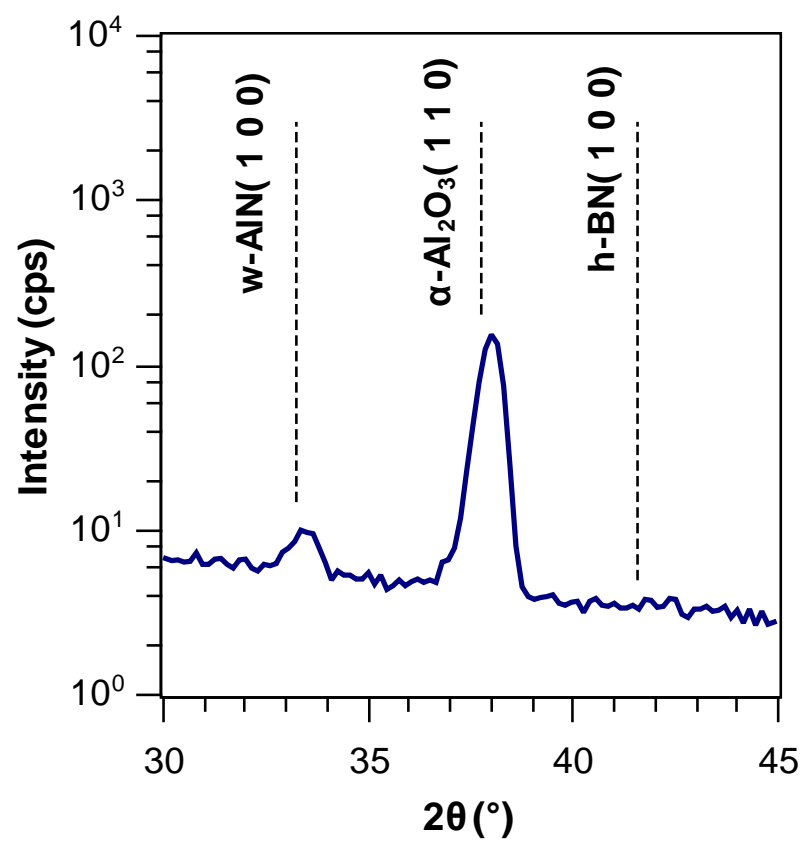

The $\{110\}$ planes of $\mathrm{sp}^{2}$-BN cannot be used to determine the BN polytype. By rotating the sample by $30^{\circ}$, it is possible to use GID to investigate the presence of the $\{100\}$ planes of h-BN, as this family of planes is extinct in the case of r-BN. ${ }^{22,24}$ The 
result is shown in Figure 2.(b), where only diffraction from the aluminum nitride buffer and the sapphire substrate is detected. This shows that it is possible to obtain polytype-pure r-BN films from TMB. In a few films, diffraction of h-BN inclusions could be detected by GID, as previously reported $\mathrm{in}^{25}$.

The twinning of the r-BN films was also investigated by acquiring azimuthal scans of the $\{101\}$ of planes of r-BN. These planes have a three-fold symmetry as dictated by rhombohedral crystal system, whereas the $\varphi$-scan in Figure 3 shows six peaks for r-BN\{101\}. This originates from the presence of twin crystals that are rotated by $60^{\circ}$. From this result, two in-plane epitaxial relationship can be determined to: $\mathrm{r}-\mathrm{BN}[110]\|\mathrm{w}-\mathrm{AlN}[110]\| \alpha-\mathrm{Al}_{2} \mathrm{O}_{3}[100]$ and $\mathrm{r}-\mathrm{BN}[110]\|\mathrm{w}-\mathrm{AlN}[110]\| \alpha-$ $\mathrm{Al}_{2} \mathrm{O}_{3}[\overline{100}]$. Twinning of r-BN has been reported in previous works for films deposited on sapphire ${ }^{9}$ and $\mathrm{SiC}^{10}$ and is to be expected due to the 6-fold symmetry of the AlN buffer layer and of the hexagonal polytypes of silicon carbide, respectively.

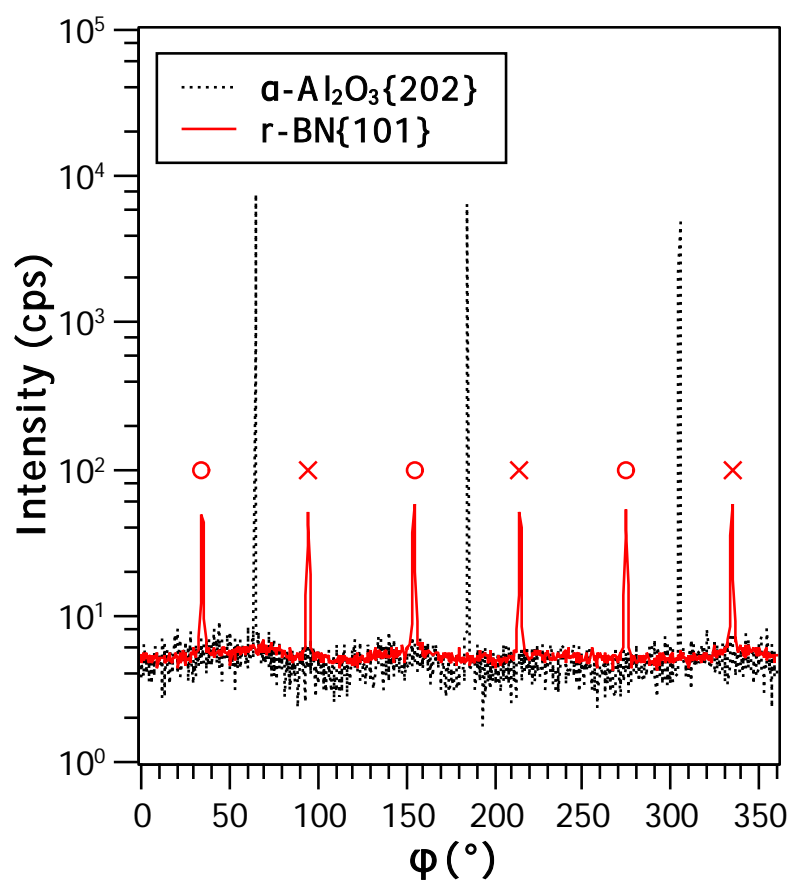

\section{B. Deposition process}


In contrast to r-BN deposited from $\mathrm{TEB}^{9}$, epitaxial films were obtained in a wider range of N/B ratios and lower pressures using TMB at $1400{ }^{\circ} \mathrm{C}$.

At fixed pressure, $\mathrm{NH}_{3}$ /TEB ratios below 460 and above 770 were shown to strongly affect r-BN epitaxy ${ }^{9}$, whereas $\mathrm{NH}_{3} / \mathrm{TMB}$ between 321 and 1286 resulted in epitaxial r-BN, without having any influence on the crystal quality from $2 \theta / \omega$ scans for N/B ratios above 643, as shown in Figure 4 (a) by the full width at half maximum (FWHM) values from $\theta / 2 \theta$ scans of $r-B N(003)$. For comparison, the FWHM of $2 \theta / \omega$ diffractograms of $\alpha-\mathrm{Al}_{2} \mathrm{O}_{3}(006)$ was $0.06^{\circ}$ and the FWHM of epitaxial r-BN deposited from TEB on nitridated sapphire was reported to be $0.3^{\circ} \mathrm{in}^{9}$. Figure 4 (b) indicates an optimal N/B ratio of 964 . This is higher than the value observed for decomposition of TEB (N/B around 615-640) and can be explained by the fact that at a lower process temperature the activation of the $\mathrm{NH}_{3}$ molecule is less favorable ${ }^{26}$. In Figure 4 (c), the crystal quality is shown to increase while decreasing the process pressure as illustrated by the proportional decrease in FWHM of $\theta / 2 \theta$ scans of $r-B N(003)$ from 0.43 to 0.29 with decreasing process pressure from 90 to 30 mbar. Interestingly, Figure 4 (d) shows that at fixed N/B ratios, the pressure does not affect the total amount of coherently diffracting domains along the c-axis, i.e. the proportion of crystallites is independent of the total pressure at these experimental conditions.

From our previous studies on CVD of B-C film from $\mathrm{TEB}^{2}$ and $\mathrm{TMB}^{14}$, we note that TEB deposits B-C:H films at $400{ }^{\circ} \mathrm{C}$ while TMB deposits films only at 700 ${ }^{\circ} \mathrm{C}$. This points to slower decomposition kinetics of TMB compared to TEB. In CVD of BN films, we speculate that the slower kinetics of TMB is then better matched to the slow decomposition kinetics of ammonia leading to a more well-matched deposition chemistry for $\mathrm{B}$ and $\mathrm{N}$ at the growth zone in the reactor, as discussed in the literature ${ }^{27}$. This allows a reduction of the overall deposition temperature and a wider 
N/B range for epitaxial growth. However, the optimal N/B ratio is then also shifted to a higher value. 
(a)

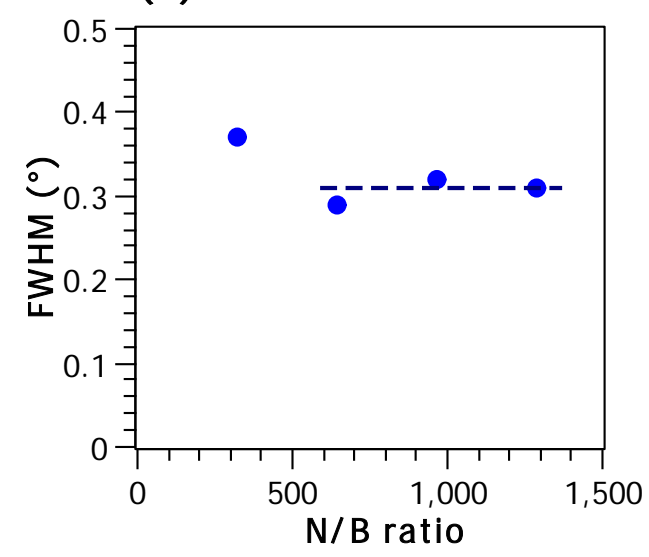

(b)

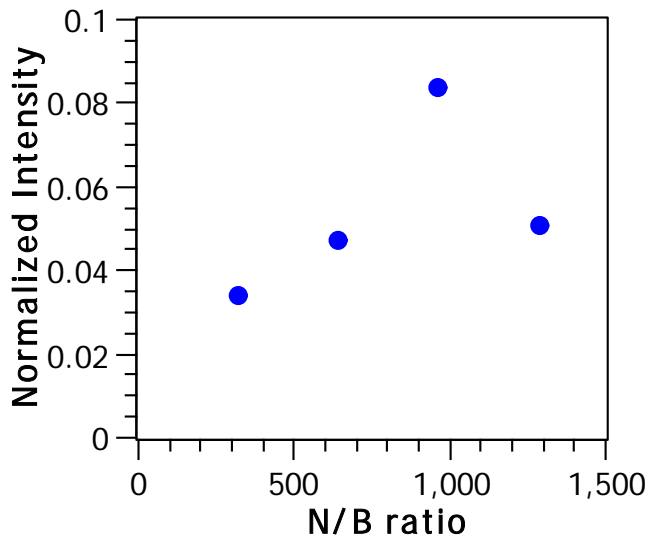

(c)

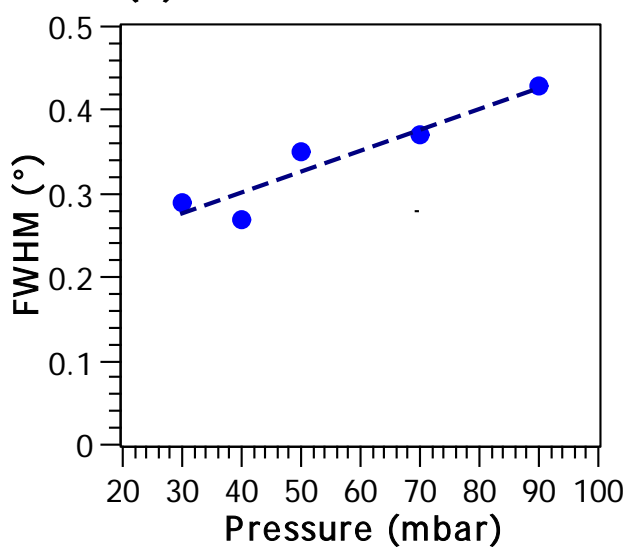

(d)

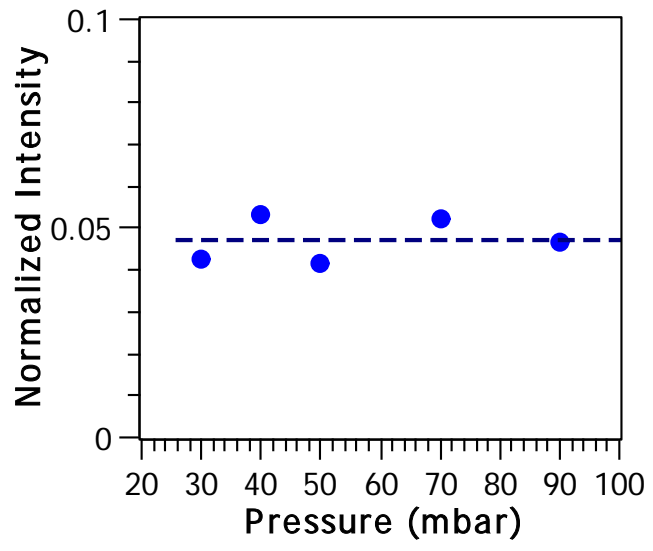


Regarding the composition of the films, ToF-ERDA gives 44.5 at\% B, 46.1 at\% $\mathrm{N}$ (B:N ratio of 1:1.04), 4.3 at\% C , 3.8 at\% O and 1.1 at\% $\mathrm{H}$ in an r-BN film deposited at $1400{ }^{\circ} \mathrm{C}, 40$ mbar, 0.9 sccm TMB and $\mathrm{NH}_{3} / \mathrm{TMB}$ ratio of 643 . This can be compared to the $\mathrm{B}: \mathrm{N}$ ratio of 1:0.98; $\mathrm{O}, \mathrm{H}$ of 0.1 at\%, 1 at $\%$, respectively, and $\mathrm{C}$ being less than 0.1 at\% (below detection threshold) for a film deposited at $1500{ }^{\circ} \mathrm{C}$, 70 mbar, $0.7 \mathrm{sccm}$ TEB and $\mathrm{NH}_{3} / \mathrm{TEB}=643 .{ }^{8}$ As for films deposited from TEB, silicon was below the detection limit of the technique (at best $0.1 \%) .{ }^{16}$ From our previous studies on CVD of B-C films from $\mathrm{TEB}^{2}$ and $\mathrm{TMB}^{14}$, we note that the $\mathrm{B}$ containing species, active for the film growth, are different when TMB and TEB are used. When TMB yields boron species with methyl groups while TEB yields boron species with ethyl groups. This renders different surface chemistry for the removal of carbon from the surface. Ethyl groups can undergo $\beta$-elimination while methyl groups must be removed by the more energetically demanding $\alpha$-elimination or by assistance of another species like hydrogen radicals. This can explain the higher carbon content in the BN films deposited by TMB. Similar trends have been observed for the pairs trimethylaluminum/triethylaluminum and trimethylgallium/triethylgallium for $\mathrm{Al}_{\mathrm{x}} \mathrm{Ga}_{1-}$ ${ }_{\mathrm{x}} \mathrm{As}^{28}, \mathrm{GaAs}^{28}, \mathrm{In}_{\mathrm{x}} \mathrm{Ga}_{1-\mathrm{x}} \mathrm{As}^{29}$ and $\mathrm{GaN}^{30}$. We speculate that the oxygen content is due to contamination due to air exposure after deposition.

Similarly as reported for $\mathrm{TEB}^{16}$, the deposition process using TMB is dependent on the background silicon concentration. In the absence of silane, the intensity of the (003) diffraction peak of r-BN is significantly reduced and the peak broadens as shown in Figure 5. 


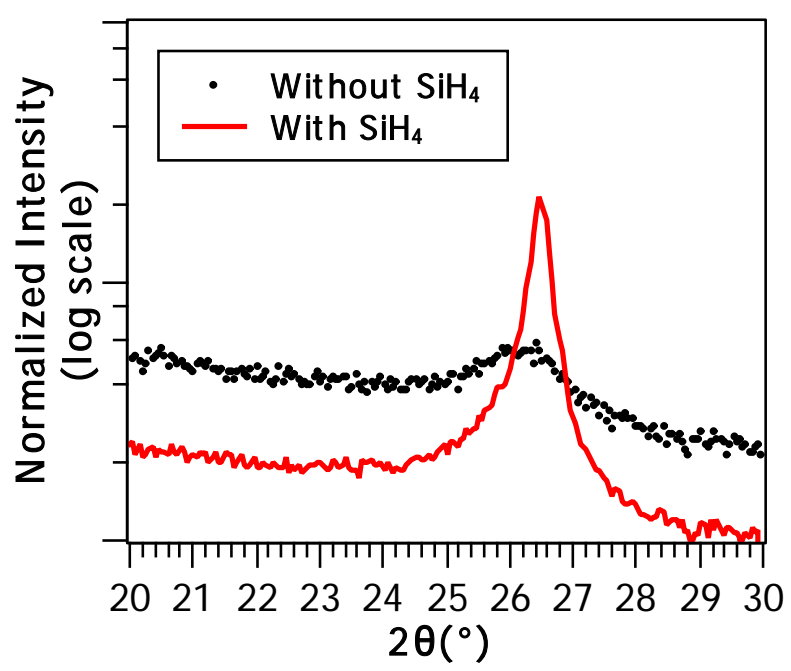

\section{CONCLUSIONS}

We demonstrate a deposition process for epitaxial r-BN on $\alpha-\mathrm{Al}_{2} \mathrm{O}_{3}(001)$ from a reaction between $\mathrm{TMB}$ and $\mathrm{NH}_{3}$ in hydrogen. Epitaxial growth was achieved at $1300{ }^{\circ} \mathrm{C}$ and with the best conditions at a deposition temperature of $1400{ }^{\circ} \mathrm{C}$. The epitaxial relationships are: $\mathrm{r}-\mathrm{BN}[001]\|\mathrm{w}-\mathrm{AlN}[001]\| \quad \alpha-\mathrm{Al}_{2} \mathrm{O}_{3}[001]$ out-of-plane and in-plane r-BN[110] \|| w-AlN[110] \| $\alpha-\mathrm{Al}_{2} \mathrm{O}_{3}[100]$ and $\mathrm{r}-\mathrm{BN}[110]\|\mathrm{w}-\mathrm{AlN}[110]\| \alpha-$ $\mathrm{Al}_{2} \mathrm{O}_{3}[\overline{1} 00]$ due to twinning. At $1400{ }^{\circ} \mathrm{C}$, the deposition process is shown to have a more favorable process window for epitaxy at investigated N/B ratios and process pressures and where the crystal quality of the films was the highest for a N/B ratio of 964 and a deposition pressure below 40 mbar. ToF-ERDA gives 44.5 at\% B, 46.1 at\% N, 4.3 at\% C, 3.8 at\% $\mathrm{O}$ and 1.1 at $\% \mathrm{H}$, where the $\mathrm{C}$ and the $\mathrm{O}$ contents in the investigated film are higher compared to a film deposited with TEB under similar conditions.

\section{ACKNOWLEDGMENTS}


This work was supported by the Swedish Foundation for Strategic Research (SSF) and contract IS14- 0027. H.P. and H.H. acknowledge financial support from the Swedish Government Strategic Research Area in Materials Science on Advanced Functional Materials at Linköping University (Faculty Grant SFO-Mat-LiU No. 200900971). Dr. Carina Höglund is acknowledged for her assistance with the ion beam analysis. The authors are grateful for access to the Tandem Laboratory at Uppsala University.

\section{SUPPLEMENTAL INFORMATION}

See supplementary material at [URL will be inserted by AIP Publishing] for Fourier Transform Infrared Spectroscopy (FTIR)

\section{References}

${ }^{1}$ J.S. Lewis, S. Vaidyaraman, W.J. Lackey, P.K. Agrawal, G.B. Freeman, and E.K. Barefield, Mater. Lett. 27, 327 (1996).

${ }^{2}$ M. Imam, K. Gaul, A. Stegmüller, C. Höglund, J. Jensen, L. Hultman, J. Birch, R. Tonner, and H. Pedersen, J. Mater. Chem. C 3, 10898 (2015).

${ }^{3}$ H. Pedersen, C. Höglund, J. Birch, J. Jensen, and A. Henry, Chem. Vapor. Depos. 18, $221(2012)$.

${ }^{4}$ H.M. Manasevit, W.B. Hewitt, A.J. Nelson, and A.R. Mason, J. Electrochem. Soc. 136, 3070 (1989).

${ }^{5}$ K. Nakamura, J. Electrochem. Soc. 133, 1120 (1986).

${ }^{6}$ Y. Kobayashi, T. Akasaka, and T. Makimoto, J. Cryst. Growth 310, 5048 (2008). 
${ }^{7}$ Y. Kobayashi, H. Hibino, T. Nakamura, T. Akasaka, T. Makimoto, and N.

Matsumoto, Jpn. J. Appl. Phys. 46, 2554 (2007).

${ }^{8}$ M. Chubarov, H. Pedersen, H. Högberg, V. Darakchieva, J. Jensen, P.O.Å. Persson, and A. Henry, Phys. Status Solidi - R 5, 397 (2011).

${ }^{9}$ M. Chubarov, H. Pedersen, H. Högberg, J. Jensen, and A. Henry, Cryst. Growth Des. 12, 3215 (2012).

${ }^{10}$ M. Chubarov, H. Pedersen, H. Högberg, Z. Czigany, and A. Henry, CrystEngComm 16, 5430 (2014).

${ }^{11}$ N. Coudurier, R. Boichot, F. Mercier, R. Reboud, S. Lay, E. Blanquet, and M. Pons, Physcs. Proc 46, 102 (2013).

${ }^{12}$ M. Chubarov, H. Pedersen, H. Högberg, A. Henry, and Z. Czigány, J. Vac. Sci. Technol. A Vacuum, Surfaces, Film. 33, 061520 (2015).

${ }^{13}$ R. Dahal, J. Li, S. Majety, B.N. Pantha, X.K. Cao, J.Y. Lin, and H.X. Jiang, Appl. Phys. Lett. 98, 1 (2011).

${ }^{14}$ M. Imam, L. Souqui, J. Herritsch, A. Stegmüller, C. Höglund, S. Schmidt, R. HallWilton, H. Högberg, J. Birch, R. Tonner, and H. Pedersen, J. Phys. Chem. C 121, 26465-26471 (2017).

${ }^{15}$ A. Maity, T.C. Doan, J. Li, J.Y. Lin, and H.X. Jiang, Appl. Phys. Lett. 109, 072101 (2016).

${ }^{16}$ M. Chubarov, H. Pedersen, H. Högberg, and A. Henry, CrystEngComm 15, 455 (2013).

${ }^{17}$ W. Kern, J. Electrochem. Soc. 137, 1887 (1990).

${ }^{18}$ G.S. Ross, D. Enagonio, C.A. Hewitt, and A.R. Glasgow, J. Res. NBS. A Phys. Ch. 66A, 59 (1962).

${ }^{19}$ K. Arstila, J. Julin, M.I. Laitinen, J. Aalto, T. Konu, S. Kärkkäinen, S. Rahkonen, 
M. Raunio, J. Itkonen, J. Santanen, T. Tuovinen, and T. Sajavaara, Nucl. Instrum.

Meth. B 331, 34 (2014).

${ }^{20}$ D. Belforti, B. Bovarnick, and S. Blum, Nature 190, 901 (1961).

${ }^{21}$ R.S. Pease, Acta Crystallogr. 5, 356 (1952).

${ }^{22}$ T. Sato, P. Japan Acad. 61, 459 (1985).

${ }^{23}$ M. Chubarov, H. Pedersen, H. Högberg, S. Filippov, J.A.A. Engelbrecht, J.

O’Connel, and A. Henry, Phys. B Condens. Matter 439, 29 (2014).

${ }^{24}$ M. Chubarov, H. Högberg, A. Henry, and H. Pedersen, J. Vac. Sci. Technol. A 36, 030801 (2018).

${ }^{25}$ M. Chubarov, H. Pedersen, H. Högberg, Z. Czigány, M. Garbrecht, and A. Henry, Chem. Mater. 27, 1640 (2015).

${ }^{26}$ K. Rönnby, S.C. Buttera, P. Rouf, S. Barry, L. Ojamäe, and H. Pedersen, Preprint DOI: 10.26434/chemrxiv.7067687.v2 (2018).

${ }^{27}$ P. Stenberg, Ö. Danielsson, E. Erdtman, P. Sukkaew, L. Ojamäe, E. Janzén, and H. Pedersen, J. Mater. Chem. C 5, 5818 (2017).

${ }^{28}$ T.F. Kuech, E. Veuhoff, T.S. Kuan, V. Deline, and R. Potemski, J. Cryst. Growth 77, 257 (1986).

${ }^{29}$ R.W. Glew, K. Grim-Bogdan, N. Tzafaras, and S. Nakahara, J. Electron. Mater. 29, $146(2000)$.

${ }^{30}$ Q. An, A. Jaramillo-Botero, W.G. Liu, and W.A. Goddard, J. Phys. Chem. C 119, 4095 (2015).

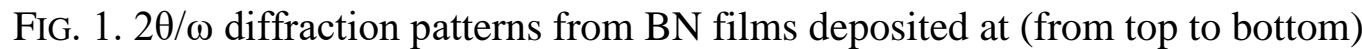
$1485,1400,1300$, and $1200{ }^{\circ} \mathrm{C}$ for $120 \mathrm{~min}$, using a process pressure of $70 \mathrm{mbar}$ and N/B $=643$. The bulk of the carrier flow consisted of $5000 \mathrm{sccm} \mathrm{H}_{2}$, the TMB flow 
was set to $0.7 \mathrm{sccm}$ diluted in $150 \mathrm{sccm} \mathrm{H}_{2}$ and the $\mathrm{Si} / \mathrm{B}$ ratio was 0.037 . The $\mathrm{NH}_{3}$ flow applied for nitridation of the $\alpha-\mathrm{Al}_{2} \mathrm{O}_{3}(001)$ substrate was $500 \mathrm{sccm}$.

FIG. 2. (a) GID diffractogram aligned on r-BN(110) $\left(\varphi=124.48^{\circ}, \psi=89.43^{\circ}\right)$ revealing the epitaxial relationship of a sp ${ }^{2}-\mathrm{BN}$ film deposited at $1400{ }^{\circ} \mathrm{C}$ and 55 mbar. The bulk of the carrier flow consisted of $6400 \mathrm{sccm} \mathrm{H}_{2}$, the TMB flow was set to $0.9 \mathrm{sccm}$ diluted in $191 \mathrm{sccm} \mathrm{H}_{2}$ and the N/B and Si/B ratios were 707 and 0.037, respectively. (b) GID diffractogram of the same film as in Figure 2.(a), but rotated $30^{\circ}$ $\left(\varphi=154.48^{\circ}, \psi=89.39^{\circ}\right)$, showing extinction of the (100) planes of $\mathrm{sp}^{2}-\mathrm{BN}$.

FIG. 3. XRD $\varphi$-scans of r-BN $\{101\}\left(2 \theta=42.6835^{\circ}, \psi=77.61^{\circ}\right)$ and $\alpha-\mathrm{Al}_{2} \mathrm{O}_{3}\{202\}(2 \theta$ $\left.=46.161^{\circ}, \psi=72.20^{\circ}\right)$. Diffraction from crystals oriented $-30^{\circ}$ with respect to the substrate is indicated by circles, diffraction from crystals oriented $+30^{\circ}$ is indicated by crosses.

FIG. 4. (a, b) Dependence of the FWHM (a) and of the normalized intensity (b) of

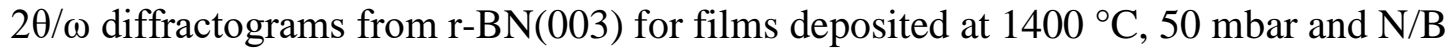
ratios ranging from 321 to 1286 . The carrier gas flow was changed to keep the same residence time inside the hot zone. To discard the effects of the buffer layer, the $\mathrm{NH}_{3}$ flow during nitridation was adjusted so that the partial pressure of $\mathrm{NH}_{3}$ was the same for each sample. (c, d) Evolution of the FWHM (c) and of the normalized intensity (d) of $2 \theta / \omega$ diffractograms of r-BN(003) for films deposited at $1400^{\circ} \mathrm{C}, \mathrm{N} / \mathrm{B}=643$ and pressure from 30 to 90 mbar. The nitridation conditions were the same for each film i.e. $636 \mathrm{sccm} \mathrm{NH}_{3}$ in $6400 \mathrm{sccm} \mathrm{H}_{2}$ at 40 mbar. The TMB flow was $0.9 \mathrm{sccm}$ and mole fractions were the same as in Figure 1. Lines are guide for the eyes. 
FIG. 5. (00l) diffraction peak of BN films deposited at $1400^{\circ} \mathrm{C}, \mathrm{N} / \mathrm{B}=643$ and 50 mbar with minute amounts of $\mathrm{SiH}_{4}(\mathrm{Si} / \mathrm{B}=0.037$, in red) and without (in black). 